\title{
Multicistronic Lentiviral Vector-Mediated Striatal Gene Transfer of Aromatic L-Amino Acid Decarboxylase, Tyrosine Hydroxylase, and GTP Cyclohydrolase I Induces Sustained Transgene Expression, Dopamine Production, and Functional Improvement in a Rat Model of Parkinson's Disease.
}

\author{
Mimoun Azzouz, ${ }^{*}$ Enca Martin-Rendon, ${ }^{\star}$ Robert D. Barber, Kyriacos A. Mitrophanous, Emma E. Carter, \\ Jonathan B. Rohll, Susan M. Kingsman, Alan J. Kingsman, and Nicholas D. Mazarakis \\ Oxford BioMedica (UK) Ltd., Oxford OX4 4GA, United Kingdom
}

Parkinson's disease (PD) is a neurodegenerative disorder characterized by the selective loss of dopaminergic neurons in the substantia nigra. This loss leads to complete dopamine depletion in the striatum and severe motor impairment. It has been demonstrated previously that a lentiviral vector system based on equine infectious anemia virus (EIAV) gives rise to highly efficient and sustained transduction of neurons in the rat brain. Therefore, a dopamine replacement strategy using EIAV has been investigated as a treatment in the 6-hydroxydopamine (6-OHDA) animal model of PD. A self-inactivating EIAV minimal lentiviral vector that expresses tyrosine hydroxylase $(\mathrm{TH})$, aromatic amino acid dopa decarboxylase (AADC), and GTP cyclohydrolase $1(\mathrm{CH} 1)$ in a single transcription unit has been generated. In cultured striatal neurons transduced with this vector, $\mathrm{TH}, \mathrm{AADC}$, and $\mathrm{CH} 1$ proteins can all be detected. After stereo- tactic delivery into the dopamine-denervated striatum of the 6-OHDA-lesioned rat, sustained expression of each enzyme and effective production of catecholamines were detected, resulting in significant reduction of apomorphine-induced motor asymmetry compared with control animals $(p<0.003)$. Expression of each enzyme in the striatum was observed for up to 5 months after injection. These data indicate that the delivery of three catecholaminergic synthetic enzymes by a single lentiviral vector can achieve functional improvement and thus open the potential for the use of this vector for gene therapy of late-stage PD patients.

Key words: Parkinson's disease; dopamine replacement; lentiviral vector; gene therapy; multicistronic vector; 6-OHDA; functional recovery
The pathological hallmark of Parkinson's disease (PD) is the selective loss of the dopaminergic neurons in the substantia nigra pars compacta (SNc) and depletion of the neurotransmitter dopamine (DA) in the striatum. PD affects $\sim 1 \%$ of the population over the age of 55 years, causing rigidity, resting tremor, and motor function impairment. The severity of the disease appears to be proportional to the loss of dopaminergic input to the striatum from the SNc. At the onset of symptoms in PD (Hoehn and Yahr stage I; Hoehn and Yahr, 1967), 40\% of the nigrostriatal efferents have been lost, whereas by the later stages (Hoehn and Yahr stage IV; Hoehn and Yahr, 1967), complete cell death of these neurons ensues (Kish et al., 1988).

The dopamine biosynthetic pathway includes the enzymes tyrosine hydroxylase $(\mathrm{TH})$, which catalyzes the synthesis of L-3,4-

\footnotetext{
Received May 22, 2002; revised Sept. 3, 2002; accepted Sept. 6, 2002.

We thank Fiona Ellard, Anna Olsen, Lucy Walmsley, Wendy Blakemore, Catherine Probert, and Susan Izadkhasti for lentiviral production; Scott Ralph for assistance in dissection of striata; Dr. John Olsen (University of North Carolina) for providing the bicistronic plasmid pBLEP; Dr. Deniz Kirik (Lund University) for helpful advice on the 6-OHDA rat model and critical reading of this manuscript; Dr. Boyd Hartman and Dr. C. Cozzari for the generous gift of the ChAT antibody; Dr. Doug Jolly (BioMedica Inc.), Dr. Carl Rosenblad (NsGene), and Dr. Peter Jenner (King's College, London, UK) for critically reading this manuscript; and the Department of Human Anatomy and Genetics of Oxford University.

*M.A. and E.M.-R. contributed equally to this work.

Correspondence should be addressed to Dr. Nicholas D. Mazarakis, Oxford BioMedica (UK) Ltd., Medawar Centre, Robert Robinson Avenue, The Oxford Science Park, Oxford OX4 4GA, UK. E-mail: n.mazarakis@oxfordbiomedica.co.uk. Copyright (C) 2002 Society for Neuroscience 0270-6474/02/2210302-11\$15.00/0
}

dihydroxyphenylalanine (L-dopa), and aromatic amino acid dopa decarboxylase (AADC), which converts L-dopa to dopamine. Additionally, TH has a requirement for a cofactor, tetrahydrobiopterin, the biosynthesis of which is rate-limited by GTPcyclohydrolase 1 (CH1). Expression of $\mathrm{CH} 1$ further stabilizes $\mathrm{TH}$ expression and increases TH activity (Leff et al., 1998; Kirik et al., 2002), and it has been reported that $\mathrm{CH} 1$ is depleted in PD striatum (Nagatsu and Ichinose, 1997).

One fundamental treatment for PD is the oral administration of L-dopa, the precursor of dopamine, which can restore a varying degree of motor function (Nagatsu, 1992). At late stages of the disease, the systemic administration of L-dopa becomes less effective in treating the movement impairment and has marked deleterious side effects. To combat decreasing DA production in the striatum, a cell replacement approach, using intracerebral grafting of human fetal mesencephalic neurons, has proved to be beneficial and long-lasting in a number of patients (Barker and Dunnett, 1999; Piccini et al., 1999; Freed et al., 2001). Gene therapy approaches for PD have aimed to either neuroprotect by delivering neurotrophic factors such as glial cell-derived neurotrophic factor (GDNF; Bensadoun et al., 2000; Bjorklund et al., 2000; Deglon et al., 2000; Kordower et al., 2000) or to replace dopamine in the striatum (Shen et al., 2000; Muramatsu et al., 2002). The former strategy is likely to be suited to early stage PD patients, whereas the latter strategy, designed for late-stage PD, has mainly been explored using adenoassociated virus (AAV) vectors. However, the limited cloning capacity of AAV vectors 
( $\sim 5 \mathrm{~kb})$ has restricted the number of genes that could be delivered with such vectors. Either two (Fan et al., 1998) or three (Shen et al., 2000; Muramatsu et al., 2002) viral vectors have had to be used to deliver catecholaminergic enzymes to the striatum in animal models of $\mathrm{PD}$, and these have resulted in improvements in motor behavior. In other experiments, the two-vector AAV system failed to produce correction of motor asymmetry in the 6-OHDA rat model but resulted in long-term production of L-dopa that could restore feeding behavior in the TH-deficient mouse (Mandel et al., 1998; Szczypka et al., 1999, 2001). By contrast, substantial functional improvement was observed after intrastriatal coexpression of $\mathrm{CH} 1$ and $\mathrm{TH}$ in 6-OHDA-lesioned animals using AAV (Kirik et al., 2002). In an alternative approach, AAV has been used to deliver AADC in the striatum of animal models of PD, with peripheral administration of L-dopa as a prodrug, with some success (Leff et al., 1999; Bankiewicz et al., 2000; Sanchez-Pernaute et al., 2001). No lentiviral vectors have been used to date for dopamine replacement in PD models. Taking into account the experience of other groups with viral vectors reported in the literature and the fact that fetal dopaminergic transplants in the striatum have the most efficacious therapy to date, it was decided to develop dopamine replacement gene therapy approach for PD. A nonprimate lentiviral vector system based on the equine infectious anemia virus (EIAV) has been developed that has a high safety profile and the potential to be used in gene therapy protocols in the clinic (Mitrophanous et al., 1999; Mazarakis et al., 2001). A self-inactivating (SIN), tricistronic EIAV vector genome has been developed, which encodes the three genes essential in the biosynthesis of dopamine (AADC, TH, and CH1) linked by two internal ribosome entry sites (IRESs) in a single transcription unit. Results obtained in vitro and in vivo with the tricistronic vector are reported here.

\section{MATERIALS AND METHODS}

Viral vector construction. EIAV SIN vector genomes were constructed from $\mathrm{pONY} 8.0 \mathrm{Z}$ or pON Y8.0G vectors described previously (Mazarakis et al., 2001). Briefly, pONY8.0Z and pONY8.0G are minimal EIAV genomes that express the marker genes for $\beta$-galactosidase $(\beta$-gal) and green fluorescent protein (GFP), respectively, under control of the cytomegalovirus promoter (CMVp). The SIN configuration was created by making a deletion in the $\mathrm{U} 3$ region of the $3^{\prime}$ long-terminal repeat (LTR) using PCR-based techniques with pONY8.0Z as the template. The sequence of the primers used for amplification was 5'-CACCTAGCAGGCGTGACCGGTGG-3' (forward) and 5'-CCTACCAATTGTATAAAACCCCTCATAAAAACCCCAC-3' (reverse). The forward primer binds just $5^{\prime}$ of a unique $N s p \mathrm{~V}$ site in pONY8.0Z, and the reverse primer binds to the $5^{\prime}$ end of the U3 region but has a MunI site (underlined) at the $5^{\prime}$ end. Thus the PCR product includes sequences corresponding to the second exon of EIAV rev and extends through the $3^{\prime}$-polypurine tract to include 26 nucleotides immediately $5^{\prime}$ of U3. The PCR product was digested with $N s p \mathrm{~V}$ and MunI and ligated into either pONY8.0Z or pONY8.0G using the same enzymes. The SIN configuration of the resulting plasmid was confirmed by sequence analysis, and the plasmids were called pONY8.0Z SIN and pONY8.0G SIN. The pONY8.1 series of vectors (Rohll et al., 2002) are derivatives of pONY8.0 in which the env region has been completely removed by digestion with SalI and partial digestion with SapI. The overhanging ends were blunted using the T4 DNA polymerase, and the plasmids were religated. The new plasmids were called pONY8.1Z SIN and pONY8.1G SIN.

The human aromatic L-amino acid dopa decarboxylase (GenBank accession number $\mathrm{M} 76180$; $\mathrm{hAADC} 480$ ) was cloned from a human liver cDNA expression library (Clontech, Cambridge, UK) using the following primers: 5'-AADC, 5'-CGAGATCTGCCACCATGTACCCCTACGACGTGCCCGACTACGCCAACGCA-3'; and $3^{\prime}$-AADC, 5'-CGAAGCTTCTACTCCCTCTCTGCTCGC-3'. The 1485 bp PCR product was digested with $B g l \mathrm{II}$ and HindIII (underlined) and cloned into pcDNA3.1neo (Invitrogen, San Diego, CA) using the same enzymes to generate the plasmid pNE2.
Human tyrosine hydroxylase type 2 (hTH-2, GenBank accession number X05290) was cloned from human fetal mRNA from substantia nigra (Clontech) using the following primers: 5'-hTH, 5'-CGGGATCCGCCACCATGGAACAAAAACTCATCTCAGAAGAGGATCTGCCCACCCCCGACGCCACCACG-3'; and 3'-hTH, 5'-CGAAGCTTCTAGCCAATGGCACTCAGCGCATGGGC-3'. The 1400 bp PCR fragment was digested with BamHI and HindIII enzymes (underlined) and cloned into pcDNA3.1zeo (Invitrogen) digested previously with the same enzymes to generate plasmid pNE4. A truncated form of hTH-2 that lacks the first 160 amino acids $(\mathrm{TH})$ was amplified from pNE4 and cloned directly into pcDNA3.1zeo as a 1038 bp fragment using the following primers: $5^{\prime} \mathrm{TH}$, 5'-CGAAGCTTGGATCCGCCACCATGGAACAAAAACTCATCTCAGAAGAGGATCTGAAGGTCCCCTGGTTCCCAAGAAAA-3'; and $3^{\prime}-\mathrm{TH}$ described above. The new plasmid that expresses TH is called pNE4a.

The human GTP-cyclohydrolase 1 (hGTP-CH1, GenBank accession number U19523) was cloned from a human liver cDNA expression library (Clontech) using the following primers: 5' -hGTP, 5'-CGAGATCTGCCACCATGGACTACAAGGACGACGATGACGAGAAGGGCCCTGTGCGGGC-3'; and 3'-hGTP, 5'-CGAAGCTTTCAGCTCCTAATGAGAGTCAGGAA-3') and cloned into pGEMT-easy (Promega, Madison, WI). The cDNA was further subcloned into pcDNA3.1Hygro (Invitrogen) as an $800 \mathrm{bp} B g l \mathrm{II}-\mathrm{NotI}$ fragment to generate pNE6.

The $1 \mathrm{~kb}$ TH cDNA from pNE4a was cloned into pBLEP plasmid (Stutts et al., 1995) downstream of the encephalomyocarditis virus (EMCV) IRES as an NcoI-EcoRV fragment. The $0.75 \mathrm{~kb}$ GTP-CH1 cDNA from pNE6 was cloned downstream of the poliovirus IRES as an NheI-XbaI fragment. The new plasmid was called BLEP-TH-CH1. The CMVp-AADC fragment was excised from pNE2 as a BglII-EcoRV fragment and was ligated into BLEP cut with SmaI-BamHI to generate BLEP-CMV-AADC. To generate the tricistronic cassette, BLEPCMVp-AADC was digested with $B \ln \mathrm{I}-\mathrm{ClaI}$, and the resultant fragment was ligated into BLEP-TH-CH1 cut with the same enzymes. The new plasmid was called pTRIC.

EIAV vector genomes that express the tricistronic cassette were generated by ligating the 6857 bp $X h o \mathrm{I}-\mathrm{XbaI}$ fragment from pONY8.0G to the $5701 \mathrm{bp} X h o I-X b a I$ fragment from pTRIC. This first vector was called pONY8.0T. pONY8.1T SIN was created by ligating the $4580 \mathrm{bp}$ XbaI-SalI fragment from pONY8.1G SIN with the 5701 bp XbaI-XhoI fragment from pONY8.0T.

The packaging construct, rev expression plasmid, and vesicular stomatitis virus-G-protein (VSV-G) envelope used in this study were pONY3.1, pESYNrev, and pRV67 as described previously (Mazarakis et al., 2001; Rohll et al., 2002).

Viral vector production. Viral vector stocks pseudotyped with VSV-G were prepared using the human embryonic kidney (HEK) 293T transient system described previously (Soneoka et al., 1995; Mitrophanous et al., 1999; Mazarakis et al., 2001). The titers $\left[\sim 2 \times 10^{9}\right.$ transducing units (t.u.)/ml] of concentrated pONY8.1Z SIN and pONY8.1G SIN viral vectors were estimated by transduction of D17 cells. The titers $\left(\sim 1 \times 10^{9}\right.$ t.u./ml) of the tricistronic-expressing vectors were estimated using realtime quantitative reverse transcription (RT)-PCR by comparison with pONY8.1Z SIN vectors and normalized for viral RNA (Martin-Rendon et al., 2002; Rohll et al., 2002).

Neuronal cultures. The striatum was removed from Wistar rats [embryonic day 18 (E18)] according to standard procedures (Dunnett and Bjorklund, 1992) and as described previously (Mazarakis et al., 2001). After dissection, striata were pooled and were incubated in trypsin $(0.25 \%)$ for $7 \mathrm{~min}$. The trypsin was subsequently inactivated by the addition of soybean trypsin inhibitor, and the cells were dissociated in Neurobasal medium (+B27; Invitrogen), glutamine $(0.5 \mathrm{~mm})$, and penicillin and streptomycin plus DNase I $(0.05 \%)$ using a $1 \mathrm{ml}$ pipette. Cells were plated out onto poly-D-lysine-precoated eight-chamber slides (Biocoat; $2 \times 10^{5}$ cells per well, $5 \times 10^{5}$ cells $/ \mathrm{ml}$ ). Cultures were placed into a humidified $37^{\circ} \mathrm{C}$ incubator containing $5 \% \mathrm{CO}_{2}$, and $50 \%$ of the media were replaced twice weekly with fresh supplemented Neurobasal medium.

In vitro transduction. HEK293T cells were transduced in the presence of $8 \mathrm{mg} / \mathrm{ml}$ Polybrene as described previously (Mitrophanous et al., 1999). Transduced cells were passaged three times before analysis of transgene expression or genome integration. To estimate the number of EIAV genomes integrated into the host cell chromosomes, total DNA was isolated from transduced cells and analyzed by real-time quantitative PCR as described previously (Martin-Rendon et al., 2002; Rohll et al., 2002). 
Cultured striatal neurons were maintained in vitro for 6-12 d before transduction and were maintained for at least an additional $5 \mathrm{~d}$ after transduction before analysis. Before transduction, culture media $(300 \mu \mathrm{l})$ were removed from each well of the chamber slide and retained for feeding. Transduction was performed by diluting concentrated virus in supplemented Neurobasal medium and adding $100 \mu$ l to each well of the chamber slides. Five hours after the onset of transduction, half of the media containing the vector particles was removed and was replaced with 50:50 supplemented neurobasal/conditioned medium. Transgene expression was assessed by either immunocytochemistry or Western blot (see below). The catecholamines produced by transduced cells were separated by HPLC and were detected electrochemically. For immunohistochemistry, cells were fixed in $4 \%$ (w/v) paraformaldehyde (20 min on ice) and were permeabilized with $0.1 \%$ (v/v) Triton X-100 in PBS (20 min on ice). Transduction was analyzed by immunocytochemistry according to standard techniques (see below).

Western blot. Total cell extracts from transduced cells were prepared in Laemmli buffer. Approximately $30 \mu \mathrm{g}$ of total cellular protein was separated in 10\% SDS-PAGE gels and transferred to nitrocellulose membranes. The membranes were blotted with mouse monoclonal antibodies $(1: 1000)$ against the tags hemagglutinin (Roche Products, Hertfordshire, UK), C-myc (Roche), and Flag (Sigma, St. Louis, MO). Antibodies bound to the proteins were detected using HRP-labeled rabbit anti-mouse IgG (Dako, High Wycombe, UK) at a 1:2000 dilution and an ECL Western blot detection kit (Amersham Biosciences, Arlington Heights, IL).

Animals. Adult male Wistar rats weighing 220-240 gm were obtained from Harlan Olac (Bicester, UK) and housed in a standard $12 \mathrm{hr}$ light/dark cycle with ad libitum access to food and water. All surgical procedures were performed with rats under anesthesia using Hypnorm and Hypnovel (Wood et al., 1994).

Medial forebrain bundle lesions. Before any viral vector injections, rats received a 6-OHDA lesion of the right medial forebrain bundle. Anesthetized animals were placed into a stereotactic frame (Stoelting), and 6-OHDA injections were performed using a $5 \mu$ l Hamilton (Reno, NV) syringe with a 33 gauge blunt-tip needle. Anteroposterior (AP) and mediolateral (ML) coordinates were calculated from bregma, and dorsoventral (DV) coordinates were calculated from the dural surface with the incisor bar set at 2.3 below the intra-aural line. Each rat received an injection of 6-OHDA.HCl (4 $\mu \mathrm{l}$ at $4 \mu \mathrm{g} / \mu \mathrm{l}$; Sigma) dissolved in $2 \mathrm{mg} / \mathrm{ml}$ ascorbate-saline $(0.2 \%$ ascorbic acid and $0.9 \% \mathrm{NaCl})$. The solution was slowly infused at a speed of $0.5 \mu \mathrm{l} / \mathrm{min}$ and delivered at AP -4.4 , ML +1.3 , and DV -7.7 .

Initially, 24 rats were lesioned with 6-OHDA. Three weeks after 6-OHDA lesions, each of the animals was prescreened for amphetamineinduced rotational asymmetry $(2.5 \mathrm{mg} / \mathrm{kg}$, i.p.) for $90 \mathrm{~min}$. Twelve rats met the criterion of showing more than seven turns/min with amphetamine treatment and were used for the initial additional apomorphine prescreening $(0.05 \mathrm{mg} / \mathrm{kg})$. Prescreening with apomorphine was performed twice for $60 \mathrm{~min} 4 \mathrm{~d}$ apart. The purpose of this test was to stabilize rotational behavior before any viral injection.

Injection of EIAV vectors. The 12 lesioned rats meeting the selection criterion of at least seven turns/min were divided into two experimental groups. The groups were balanced according to apomorphine-induced rotational behavior before viral vector administration. The following groups were included in the present study: pON Y8.1Z SIN $(n=5)$ and pONY8.1T SIN $(n=7)$. Stereotaxic administrations were performed under Hypnorm and Hypnovel anesthesia using a $5 \mu$ l Hamilton syringe with a 33 gauge blunt-tip needle. A total of 12 unilateral 6-OHDAlesioned animals received three $2 \mu \mathrm{l}$ intrastriatal injections of viral vectors: (1) AP 0.0, ML +3.5, and DV - 4.75; (2) $\mathrm{AP}+1, \mathrm{ML}+3.5$, and $\mathrm{DV}-4.75$; and (3) AP +1.8, $\mathrm{ML}+2.5$, and $\mathrm{DV}-5$. The lentiviral solution was slowly infused at the speed of $0.2 \mu \mathrm{l} / \mathrm{min}$ using an infusion pump (World Precision Instruments). After viral vector injections, the skin was closed using a 5-0 Vicryl running suture, and after surgery, animals were kept warm until recovery was complete. All surgical procedures were approved by a local veterinarian and ethical committee and were performed according to Home Office regulations.

Behavioral analysis. To assess a possible functional benefit of viral vector treatment, apomorphine-induced rotation was tested weekly from 4 to 10 weeks after viral injection into the striatum. Rotations were assessed using an automated rotometer system (Stoelting). Animals were placed in the apparatus and allowed to habituate for 10-15 $\mathrm{min}$ before being injected with a subcutaneous dose of apomorphine $(0.05 \mathrm{mg} / \mathrm{kg})$. Clockwise turns (ipsilateral to the lesion) were counted as positive turns, whereas counterclockwise turns (contralateral to the lesion) were counted as negative turns. The net apomorphine-induced rotation by the animal was obtained by calculation of the difference between clockwise and counterclockwise turns and was monitored for $60 \mathrm{~min}$.

Histological evaluation. After rotational testing was completed (15 weeks after the lesion), rats were perfused transcardially with $0.9 \% \mathrm{NaCl}$ solution followed by $200 \mathrm{ml}$ of ice-cold $4 \%$ paraformaldehyde. Brains were dissected out, postfixed overnight in the same solution, and then transferred to $30 \%$ sucrose. Tissues were analyzed by immunohistochemistry and 5-bromo-4-chloro-3-indolyl- $\beta$-D-galactopyranoside (X-gal) reaction. Brains were cut on a sliding cryostat microtome (Leica) at a thickness of $50 \mu \mathrm{m}$ and collected as free-floating sections in PBS.

For immunostaining on cell cultures and brain sections, blocking was performed in PBS containing 10\% normal goat serum or $10 \%$ normal donkey serum as appropriate for the secondary antibodies. Primary antibodies were used as follows: anti-Flag (1:500 for cell cultures, 1:2000 for sections; Sigma); anti-HA (1:500 and 1:200 for cell cultures and striatal sections, respectively; Santa Cruz Biotechnology, Santa Cruz, CA); anti-C-myc (1:500 and 1:200 for cell cultures and striatal sections, respectively; Santa Cruz Biotechnology); anti-TH (1:1000, 1:400 Diasorin for cells and sections, respectively, or 1:200 for sections; Affiniti); anti-neuronal nuclei (NeuN; 1:500 and 1:100 for cells and tissue, respectively, Chemicon, Temecula, CA); anti-AADC (1:1000; Chemicon), antiChAT (1:1000; a gift from Drs. B. Hartman and C. Cozari, University of Minnesota, Minneapolis, MN); anti-GAD (1:500 for cell cultures; Chemicon); anti-D1 (1:100 for cell cultures; Chemicon); anti-D2 (1:100 for cell cultures; Chemicon); and anti-dopamine- and cAMP-regulated phosphoprotein 32 (DARPP32; 1:1000 for cell cultures and 1:25000 for brain sections; purchased from H. Hemmings, Cornell University, Ithaca, NY). Samples were washed three to five times with PBS and then incubated with fluorescently labeled (Alexa 488, FITC, Texas Red, Texas Red-X, or Cy3) species-specific secondary antibodies (made in either goats or donkeys) at room temperature for $2 \mathrm{hr}$ (antibodies from Molecular Probes, Eugene, OR; or Jackson ImmunoResearch, West Grove, PA). Cresyl violet was used to evaluate the presence of any cell death or damage in control and transduced striata.

Cell counts. To evaluate the number of transduced cells in the striatum, alternate sections stained for X-gal and for HA, C-myc, and Flag and ChAT immunoreactivity were counted in every fifth section throughout the entire striatum. DARPP32 cell counts were performed near the needle tracts to assess the presence of specific damage associated with production of dopamine. The counts were performed at a magnification of $40 \times$. The coefficient of error was determined as described previously by Abercrombie (1946).

Biochemical assays. To correlate catecholamine production and behavioral improvement, both HPLC analysis and rotational behavior were performed at 10 weeks. Animals were killed with an overdose of pentobarbital after the last rotational behavior assay (10 weeks after EIAV injections). Brains were rapidly removed, and striata were carefully dissected out using a tissue slicer. Striatal punches from ipsilateral and contralateral sides were taken, immediately frozen in liquid nitrogen, and stored at $-80^{\circ} \mathrm{C}$ until analysis. All samples were treated equally. To determine the level of DA and DA metabolites, striatal tissue weight was obtained before homogenizing the tissue in 10 volumes of homogenization buffer (1.2 mM HEPES, pH 7.2; $1 \%$ Triton X-100; $10 \%$ glycerol, and $1 \mathrm{~mm}$ PMSF). Catecholamines were extracted by mixing the tissue homogenates with 10 volumes of $0.1 \mathrm{M}$ perchloric acid, $0.54 \mathrm{~mm}$ EDTA, and $2 \%$ ethanol. The debris was removed by centrifugation at $4^{\circ} \mathrm{C}, 14,000$ rpm for $15 \mathrm{~min}$ and additional filtration through a Nanosep MD spin filter (Pall Filtron). The supernatants were applied to an HPLC system (Dionex) equipped with an ESA Coulochem II electrochemical detector (ESA Analytical). Catecholamines were separated using a C-18 reversed phase column (ESA Analytical) equilibrated with Cat-A-Phase (ESA Analytical) at a flow rate of $1.5 \mathrm{ml} / \mathrm{min}$ and then detected electrochemically. This HPLC assay is optimized for the detection of L-dopa, dihydroxyphenylacetic acid (DOPAC), and dopamine, with the specific peaks appearing in this order. Catecholamine detection from transduced heterologous cells in culture was performed in a similar procedure. Samples were prepared for HPLC by preincubation of the cells in a saline solution containing $100 \mu \mathrm{M}$ tyrosine. Cells were then washed once with warm PBS and incubated for $5 \mathrm{hr}$ in release buffer $(200 \mu \mathrm{l})$ consisting of (in $\mathrm{mM}$ ): $135 \mathrm{NaCl}, 1 \mathrm{MgCl}_{2}, 1.2 \mathrm{CaCl}_{2}, 2 \mathrm{NaH}_{2} \mathrm{PO}_{4}, 10$ glucose, and $56 \mathrm{KCl}$. After incubation, the buffer was removed, and catecholamines were extracted with a $10 \%$ volume $(20 \mu \mathrm{l}$ each $)$ of $\mathrm{HClO}_{4}(2 \mathrm{M})$ and $\mathrm{Na}_{2} \mathrm{~S}_{2} \mathrm{O}_{5}$ 


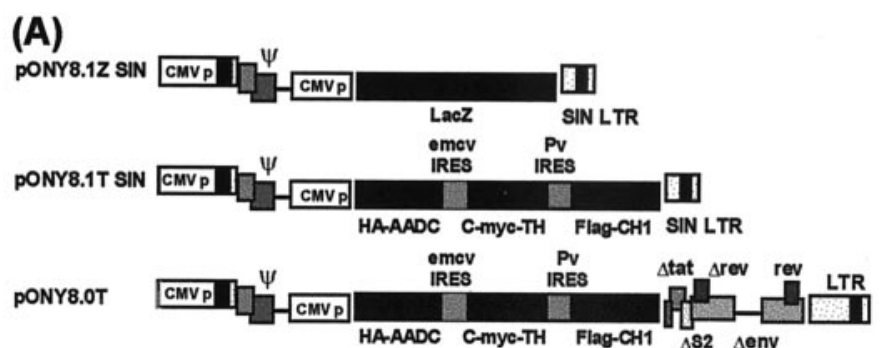

(B)

\begin{tabular}{lcc}
$\begin{array}{l}\text { Vector } \\
\text { preparation }\end{array}$ & Estimated Titer & $\begin{array}{c}\text { Relative } \\
\text { Integration }\end{array}$ \\
\hline pONY8.1Z SIN & $2 \times 10^{9} \mathrm{TU} / \mathrm{ml}$ & 11.6 \\
pONY8.1T SIN & $1 \times 10^{9} \mathrm{TU} / \mathrm{ml}$ & 11.6 \\
pONY8.0T & $1 \times 10^{9} \mathrm{TU} / \mathrm{ml}$ & 11.4
\end{tabular}

Figure 1. EIAV vectors used in this study. $A$, Genetic configuration of pONY8.1Z SIN, pONY8.1T SIN, and pONY8.0T vector genomes. $B$, Titers and integration efficiency of EIAV vectors were estimated by quantitative real-time RT-PCR (Martin-Rendon et al., 2002). Biological titers were calculated by comparison with known standards. For relative integration efficiencies, D17 cells were transduced at an MOI of 10 based on the calculated biological titers, and total DNA was isolated from the transduced cells 7-10 d after transduction. The relative integration efficiency of the different EIAV genomes in the host cells relative to $\beta$-actin ( $\Delta C t$ values) was equivalent for the three vector genomes.

(1\%), respectively, and were run immediately on the HPLC as described above.

Statistical analysis. The data obtained were analyzed for statistical significance using ANOVA or repeated measures ANOVA. When an appropriate comparison was significant, post hoc testing between the groups was performed by using simple main effects with a Bonferroni significant difference (Kirik et al., 2002) (StatView 5.0; Abacus Concepts, Calabasas, CA).

\section{RESULTS}

\section{Construction of tricistronic EIAV lentiviral vectors}

EIAV-based lentiviral vectors (Fig. $1 A$ ) were constructed expressing three genes that are involved in dopamine biosynthesis: AADC, TH, and CH1. The catalytic isoforms of the human AADC and $\mathrm{CH} 1$ were tagged with the HA and Flag epitopes, respectively, at the $\mathrm{N}$ termini of these proteins. $\mathrm{TH}$ can be induced by phosphorylation at the N-terminal region, and it is subject to feedback end product inhibition mediated by catecholamine binding to the free enzyme (Kumer and Vrana, 1996). Because it was planned to express $\mathrm{TH}$ in striatal neurons, which lack vesicular monoamine transporter 2 (VMAT2), a truncated isoform of the human $\mathrm{TH}$ gene was used in the viral vector. Specifically, the first 160 amino acids of the regulatory domain were removed by the truncation, leaving the remaining amino acids of the catalytic domain unaffected. This truncation prevents any inhibition of the enzyme by the synthesized cytoplasmic dopamine. A new start codon followed by a C-myc epitope was introduced in the $\mathrm{TH}$, for unambiguous identification of the expressed protein.

The three genes were cloned into the minimal EIAV vector genome pONY8.0 (Mazarakis et al., 2001) and the selfinactivating minimal genome pON Y 8.1 SIN as a single transcription unit (creating pONY8.0T and pONY8.1T SIN). The genes of the tricistronic cassette were linked by two IRES sequences from the EMCV and poliovirus, respectively, and expression of the cassette was driven by the CMVp. It was found that the pONY8.0T and pONY8.1T SIN can be packaged into EIAV particles as efficiently as other monocistronic control genomes, such as pONY8.0Z (which encodes $\beta$-galactosidase), as demonstrated by the high-titer vector preparations obtained for these vectors (Fig. $1 B$ ). This is despite the fact that pONY8.0T is $\sim 110 \%$ of the size of the wild-type EIAV genome. Vector particles encoding the tricistronic cassette were able to transduce heterologous cells and integrate into the host genome with the same efficiency as the control pONY8.1Z or pONY8.0G (GFP) viral vectors (Fig. $1 B)$. Taken together, these results suggest that pONY8.0T and pON Y8.1T SIN viral vectors have potential transduction efficiency similar to that of those encoding $\beta$-galactosidase or GFP.

\section{Coexpression of catecholaminergic enzymes in heterologous cell lines}

To confirm that AADC, TH, and $\mathrm{CH} 1$ were coexpressed from pONY8.1T SIN and pONY8.0T vectors, cells from the noncatecholaminergic dog osteosarcoma cell line D17 were transduced at different multiplicities of infection (MOIs; 1, 10, and 100). As positive controls, cells transiently cotransfected with expression plasmids encoding AADC (pNE2), TH (pNE4a), and $\mathrm{CH} 1$ (pNE6) were used. The expression of HA-AADC, C-myc-TH,
(A)

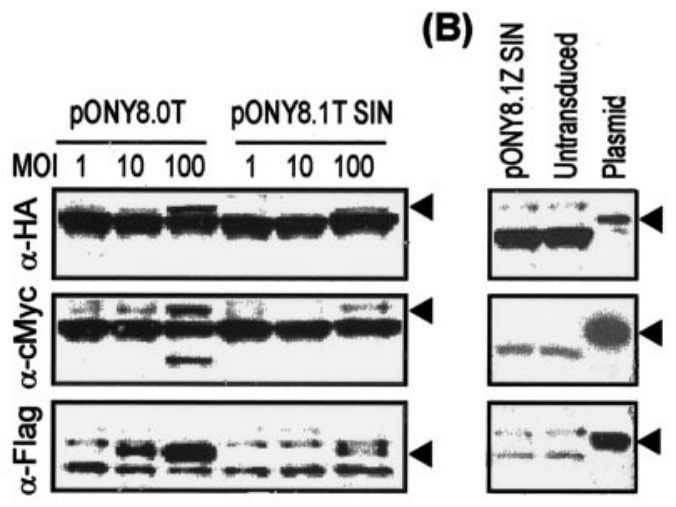

Figure 2. Expression of catecholamine biosynthetic enzymes in heterologous cell lines transduced with EIAV vectors. $A$, Western blot on total cell extracts prepared from D17 cells $8 \mathrm{~d}$ after transduction. Cells were transduced with either pONY8.0T or pONY8.1T SIN at MOIs of 1, 10, and 100 as indicated. $B$, Control blots showing extracts from cells transduced with pONY8.1Z SIN at an MOI of 100, untransduced cells, and HEK293T cells transfected with the appropriate monocistronic plasmid pNE2 (HA-AADC), pNE4a (C-myc-TH), or pNE6 (Flag-CH1). The blots were probed with mouse monoclonal antibodies against the tagged proteins at a 1:1000 dilution. Arrowheads indicate the apparent molecular weights of the tagged proteins: $52 \mathrm{kDa}$ for HA-AADC, $42 \mathrm{kDa}$ for C-myc-TH, and $26 \mathrm{kDa}$ for Flag-CH1. C, HEK293T cells were transduced with pONY8.1Z SIN, pONY8.0T, or pONY8.1T SIN at an MOI of 100, and cell lysates were prepared $10 \mathrm{~d}$ after transduction. Catecholamines were extracted from the cell lysates, separated by HPLC, and detected electrochemically. Significant production (picograms per $10^{6}$ cells) of L-dopa (white bars), DOPAC (gray bars), and dopamine (black bars) was detected in cells transduced with either pONY8.0T or pONY8.1T SIN but not cells transduced with pONY8.1Z SIN. 

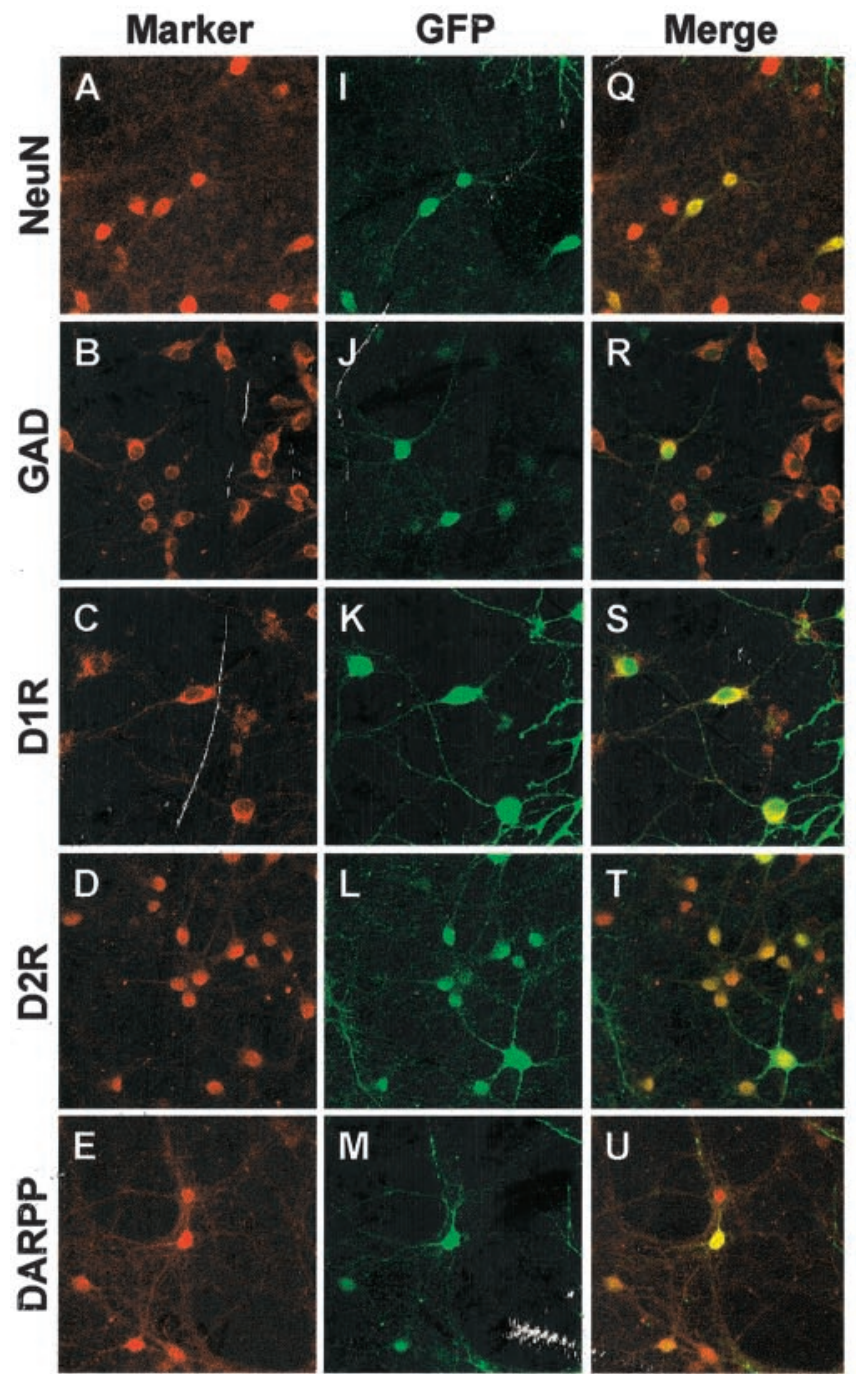

Tag

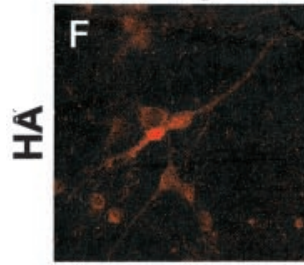

GAD
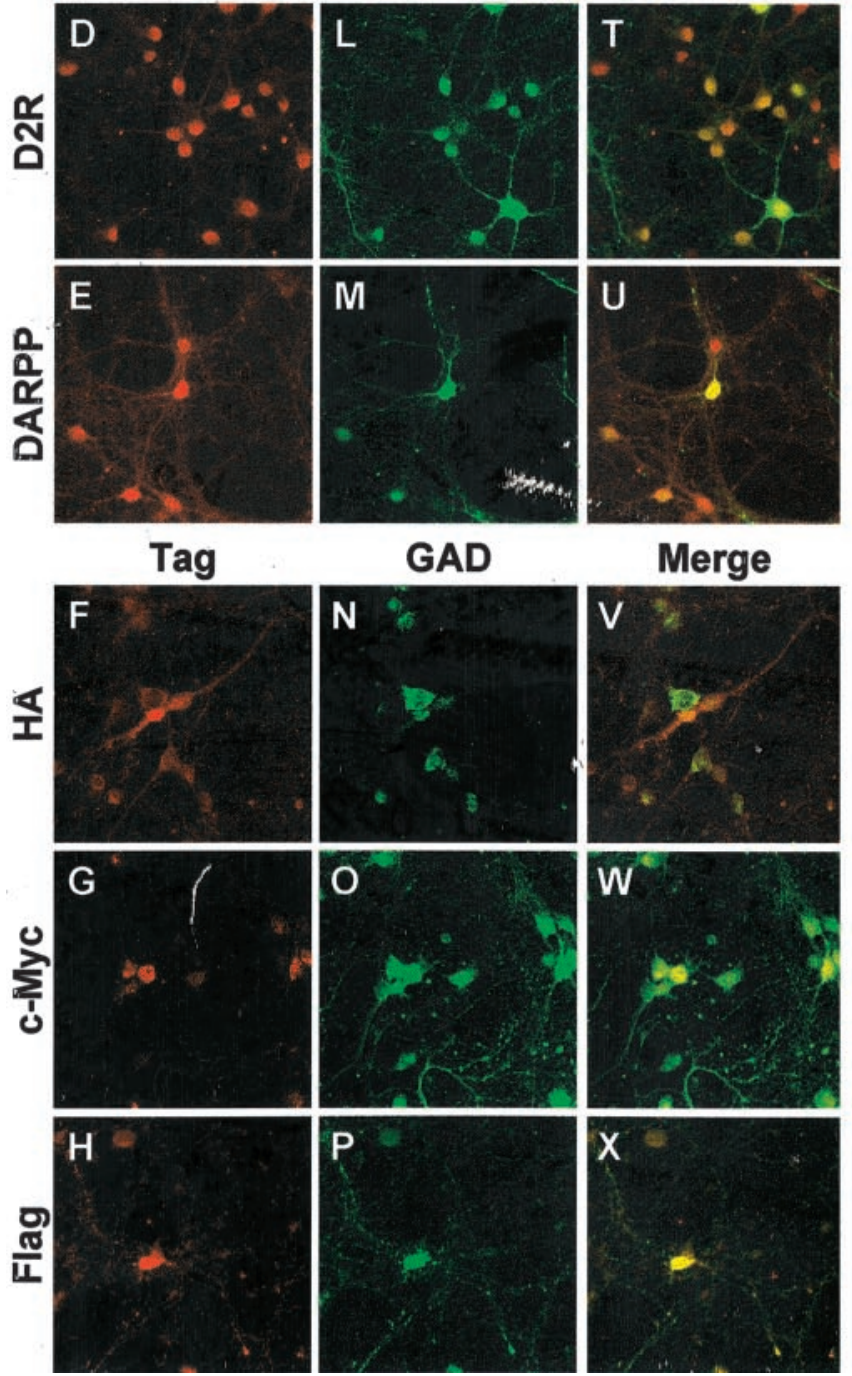

Merge
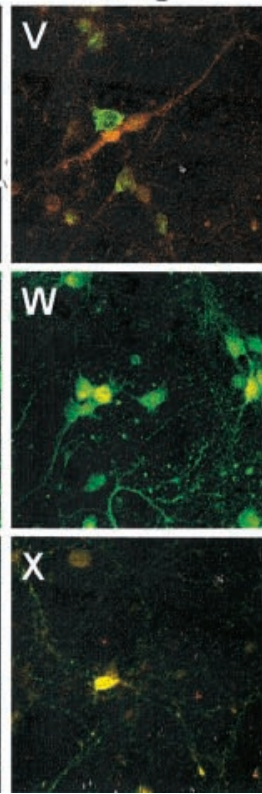

Figure 3. Confocal microscopic images demonstrating transduction of cultured striatal neurons with EIAV vectors. Striatal neurons (DIV 6) were transduced with pONY8.1G SIN at an MOI of 10 and, after an and Flag-CH1 was monitored by Western blot (Fig. $2 A, B$ ) using monoclonal antibodies against the HA, C-myc, and Flag tags. In the untransduced and mock-transduced (pON Y8.1Z SIN at an MOI of 100) cells, none of the three proteins was detected (lanes 7,8 ). In cells transduced with either pONY8.0T (Fig. $2 A$, lanes 1-3) or pONY8.1T SIN (Fig. $2 A$, lanes 4-6) vectors, all three expected bands corresponding to the $52 \mathrm{kDa} H A-A A D C, 42 \mathrm{kDa}$ $\mathrm{C}$-myc-TH, and $26 \mathrm{kDa}$ Flag-CH1 proteins, respectively, were detected. The same bands were also found in cells cotransfected with each of the three expression plasmids (Fig. 2B, lane 9).

To assess enzyme function, HEK293T cells (a noncatecholaminergic human embryonic kidney cell line) were transduced at an MOI of 100 with pONY8.1Z SIN, pONY8.1T SIN, or pON Y8.0T. Catecholamines were separated by HPLC and were detected electrochemically in cell extracts (Fig. 2C). L-dopa, dopamine, and DOPAC, the specific byproduct of dopamine metabolism by monoamine oxidase (MAO), were detected in cells transduced with both pON Y8.0T and pON Y8.1T SIN but not in the mock-transduced cells (pONY8.1Z SIN). These data indicate that the expressed proteins form catalytically active enzymes. Cells transduced with the pONY8.1T SIN vector were found to produce approximately four times more dopamine than those transduced with pON Y8.0T (Fig. 2C); therefore, pON Y8.1T SIN vectors were used in subsequent experiments.

\section{Expression of catecholaminergic enzymes in rat primary striatal neurons}

Striatal neurons, the target cell population for dopamine replacement therapy, were isolated and cultured in vitro. Neurons were obtained from E18 rats and were matured in culture for 6-12 d before transduction with EIAV vectors. In these cultures, two major populations of neurons have been described: the GABAergic medium spiny neurons, which account for $95 \%$ of the cells; and large cholinergic type 1 neurons, which make up the residual $5 \%$. Expression of specific markers (neuron-specific tubulin, NeuN, microtubule-associated protein 2, GAD, and DARPP32) was demonstrated in cultures of striatal neurons. Similarly, expression of dopamine receptors (D1R and D2R) has been localized to postsynaptic sites in the striatum (Levey et al., 1993). After transduction at day in vitro (DIV) 6 with pONY8.1G SIN, colocalization of GFP (at DIV 12) with these specific proteins can be observed (Fig. 3A-E,I-M, $Q-U$ ). No gross effects on the expression of these markers were observed after transduction (data from nontransduced cells not shown). Similar cultures that had been further aged in culture to ensure full maturation (Ariano et al., 1997; Martin-Negrier et al., 2000) were transduced at DIV 12

$\overline{\text { additional } 6 \mathrm{~d} \text { in culture, were processed for immunocytochemistry. Cells }}$ were fixed and stained with antibodies against NeuN $(A), \operatorname{GAD}(B), \mathrm{D} 1 \mathrm{R}$ $(C)$, D2R $(D)$, or DARPP $(E)$ and with the appropriate Texas Red- and Cy3-coupled secondary antibody. GFP expression was observed in the same cells $(I-M)$, and colocalization of GFP with the cell specific markers can clearly be seen in the merged images $(Q-U)$. For HPLC and catecholamine release experiments, striatal neurons were transduced with pON Y8.1Z SIN or pONY8.1T SIN (DIV 12). At DIV 19, neurons were tested for catecholamine release and were processed for immunocytochemistry. Cells transduced with pONY8.1T SIN were stained with antibodies against each of the three specific tag epitopes, HA-AADC, $\mathrm{C}$-myc-TH, and Flag-CH1 $(F-H$, respectively, all Texas Red) and were colocalized with the anti-GAD antibody $(N-P$, FITC). Merged images are shown $(V-X)$ that demonstrate that each of the three genes encoded by pONY8.1T SIN are expressed in the GABAergic medium spiny striatal neurons in culture. 
(A)

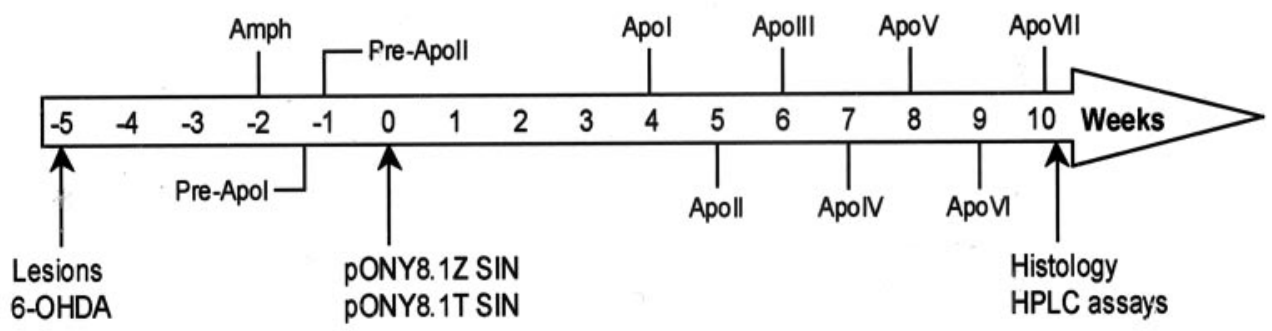

(B)

(C)
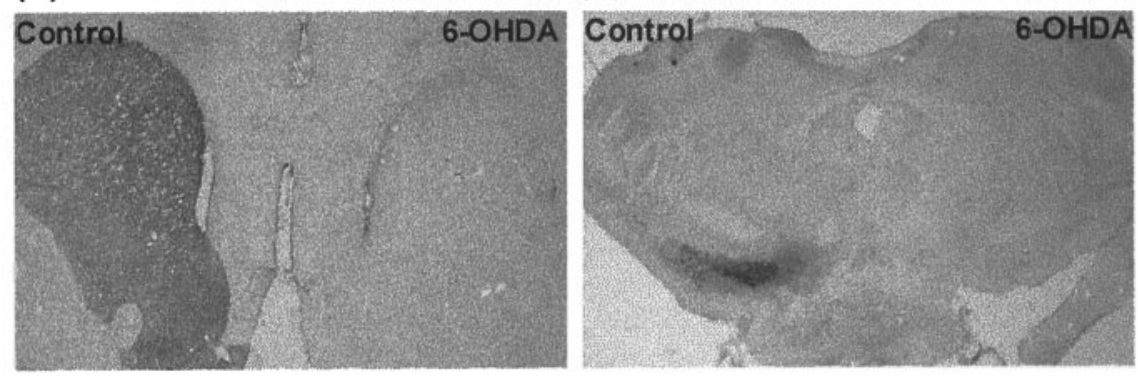

(D)

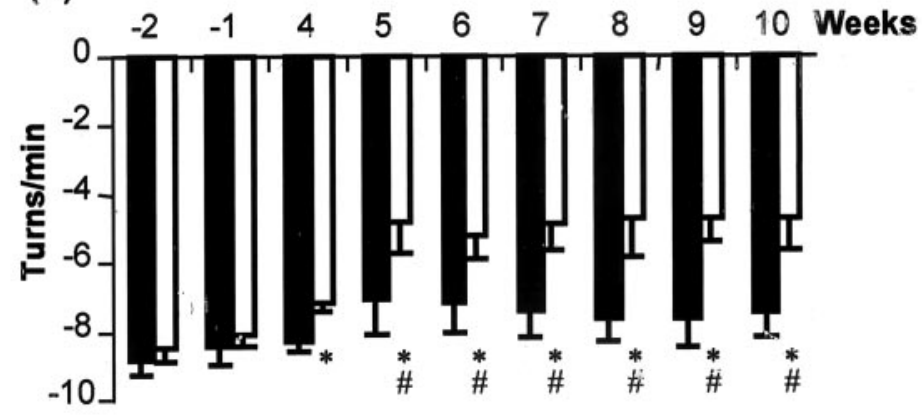

Figure 4. In vivo gene transfer of EIAV vectors in 6-OHDA-treated rats. $A$, Time course for surgery and behavioral testing from lesion ( -5 weeks) to histology and biochemical analysis ( $>10$ weeks). Medial forebrain lesions were performed 5 weeks before viral vector injections. 6-OHDA (4 $\mu \mathrm{l}$ at $4 \mu \mathrm{g} / \mu \mathrm{l}$ ) was injected into one site and induced a severe loss of TH immunoreactivity in the ipsilateral substantia nigra compacta $(B)$ and striatal terminals $(C)$. Three weeks after the 6-OHDA lesion, rats were prescreened for amphetamine $(A m p h)$ and apomorphine-induced behavioral motor asymmetry (Pre-ApoI, PreApoII, $0.05 \mathrm{mg} / \mathrm{kg}$, s.c.). Before viral injection into the striatum (4 weeks after 6-OHDA lesion), all groups showed clear apomorphine-induced contralateral rotation that was equivalent across the groups $(D)$. Viral vector injections were performed in three sites into the striatum (2 $\mu \mathrm{l} /$ site), and apomorphine-induced rotational behavior was measured weekly from 4 and 10 weeks after viral administration. Rats that were injected with pONY8.1T SIN show substantial reduction $(-48 \%)$ in rotational asymmetry that is significantly different from the pONY8.1Z SIN-treated group $(p<0.003)$. Rotations are expressed as net turns (ipsilateral to contralateral) per minute. The number of turns per minute remained relatively stable in the treated group between 4 and 10 weeks after viral administration. Asterisks indicate a significant difference from the pONY8.1Z SIN-treated control animals at each time point. The pound sign denotes a significant difference in the number of rotations from the baseline value recorded before viral injection (Pre-ApoI, PreApoII $)$, Bonferroni test, $(p<0.003)$. with pONY8.1T SIN or pONY8.1Z SIN and were assayed for expression of the tagged enzymes by immunocytochemistry and for catecholamine release by HPLC and electrochemical detection at DIV 19. The transduction efficiency of neurons was estimated to be $46 \%$ on the basis of X-gal and $\beta$-gal staining of pONY8.1Z SIN-transduced cells (data not shown). Colocalization of the tagged enzymes with the medium spiny neuron marker GAD was demonstrated (Fig. $3 F-H, N-P, V-X$ ). To measure dopamine release, cells were preloaded with $100 \mu \mathrm{M}$ tyrosine for 1 $\mathrm{hr}$ and incubated in release buffer for $5 \mathrm{hr}$. Significant dopamine production $\left(0.56 \mathrm{ng} \cdot 10^{6}\right.$ cells plated $^{-1} \cdot \mathrm{hr}^{-1} ; n=6 ; p<0.05, z$ test) was detected from cell cultures transduced with pONY8.1T SIN but not from cells transduced with pONY8.1Z SIN. These data confirm that transduction with pONY8.1T SIN results in the expression of the three dopamine synthetic enzymes and does not cause any gross decrease in viability or abnormal morphology of the striatal cultures as a result of either transduction or from increased dopamine turnover.

\section{Effect of EIAV tricistronic vectors on apomorphine-induced rotation}

To assess a possible functional benefit of this gene therapy strategy, the medial forebrain bundle (MFB) was lesioned with 6-OHDA. This is a model that gives rise to extensive degeneration in the substantia nigra and is consistent with late-stage PD. No significant decrease in body weight in lesioned rats was observed (weight loss of only 3-5\% compared with prelesion weight). After 5 weeks, the striatum was injected with viral vector, and functional recovery was assessed using apomorphine-induced motor asymmetry as indicated (Fig. $4 A$ ). Injection of 6-OHDA in the MFB induced an extensive loss of $\mathrm{TH}$ innervation in large portions of the striatum compared with the intact hemisphere (Fig. 4B). The extensive denervation of the striatum was associated with almost complete disappearance of TH-positive neurons $(>95 \%)$ in the ipsilateral substantia nigra pars compacta (Fig. $4 C$ ). Cell counts of TH-IR in the substantia nigra pars compacta showed an average of $612 \pm 11$ cells in the intact side compared with $31 \pm 9$ cells remaining in the lesioned side. These animals showed strong contralateral behavior after the administration of apomorphine ( $>400$ turns/hr) indicative of the destruction of $>98 \%$ of dopaminergic neurons in the substantia nigra (Mandel et al., 1998).

Drug-induced rotation was measured weekly during the period from 4 to 10 weeks after viral injection into the striatum. Before any viral administration, injection of apomorphine induced similar functional impairment in rotational behavior in both groups $(-8.4 \pm 1.1$ and $-8.1 \pm 0.8$ turns $/ \mathrm{min}$ in animals to be injected with pONY8.1Z and pONY8.1T, respectively). In rotational tests, significant functional recovery (a decrease in counterclockwise rotations) was observed in the pONY8.1T SIN-injected group $(n=7)$ compared with pONY8.1Z SIN-injected animals $(n=5)$ (Fig. $4 D)$. Four weeks after the intrastriatal viral injection, the pONY8.1T SIN-injected group showed less contralat- 
eral rotation than the control rats, reaching a $48 \%$ decrease 10 weeks after viral injection $(p<0.003$, significantly different from baseline values before any vector injection) (Fig. 4D). Rotational asymmetry (number of turns per minute) remained relatively stable in the treated group from 4 to 10 weeks after viral administration. These results were observed in two separate experiments using two different batches of the viral vectors. The data presented in Figure $4 D$ were collected from the second of the two experiments and confirmed the data obtained in the previous (original) experiment.

\section{Expression of $\beta$-galactosidase and tricistronic vectors in 6-OHDA-lesioned rats}

To evaluate viral vector expression, all rats used in this study received three injections ( $2 \mu$ l each) of viral vectors, either pONY8.1Z SIN $(n=5)$ or pONY8.1T SIN $(n=7)$, that were matched by viral RNA content. Ten weeks after viral injection, $\mathrm{X}$-gal staining of the brain sections from animals injected with pON Y8.1Z SIN confirmed transduction and showed strong and sustained expression of $\beta$-galactosidase in the striatum (Fig. $5 A, B)$. The transgene was expressed in an average area of $5 \mathrm{~mm}$ both rostrocaudally and dorsoventrally. More than $90 \%$ of the transduced cells had neuron-like morphology that appeared to be both medium-sized spiny and aspiny neurons commonly found in the striatum. This is consistent with previous experiments using EIAV expressing $\beta$-galactosidase (Mazarakis et al., 2001).

To determine the extent of the transduction with pONY8.1T SIN and whether HA-AADC, C-myc-TH, and Flag-CH1 were expressed in the denervated striatum, immunodetection was performed after the last rotational testing (10 weeks after viral administration). Expression of the three enzymes was monitored as described previously using antibodies against the tagged proteins (HA, C-myc, and Flag). No detection of the tags was observed in denervated striatum transduced with pONY8.1Z SIN (data not shown). However, unequivocal detection of HA, $\mathrm{C}$-myc, and Flag tags was observed in pONY8.1T SIN-injected striatum (Fig. $5 C-H$, respectively). To determine the number of transduced cells in pON Y8.1T SIN-injected striatum, cell counts were performed on anti-tag-stained sections. Injection of pON Y8.1T SIN into the striatum led to HA, C-myc, and Flag expression in $5000 \pm 700,4800 \pm 400$, and 16,000 \pm 1400 cells, respectively (Fig. $5 \mathrm{C}-\mathrm{H}$ ). Cell count data indicate threefold lower numbers of HA-AADC- and C-myc-TH-expressing cells compared with Flag-CH1-positive cells in pONY8.1T SIN-injected striatum. The reason for this is unclear, especially because the Flag-CH1 is the third enzyme in the tricistronic cassette. However, there are two potential explanations for this observation: (1) although this study reports the use of a truncated version of $\mathrm{TH}$, DA made in transduced cells may be causing feedback inhibition on TH and AADC; and (2) these two enzymes are not as stable as they would be in the nigral neurons. Nevertheless, the estimated HA- and C-myc-positive cell numbers remain relatively high. HA-, C-myc-, and Flag-positive cells were found over an average of a $3 \mathrm{~mm}$ distance along the rostrocaudal axis. Most C-myc-transduced cells were found in sections surrounding the injection site. Examination of the morphology of both HA- and $\mathrm{C}$-myc-positive cells and those expressing Flag suggested that these cells were predominantly neurons. Confocal studies confirmed the neuronal nature of cells transduced with the pONY8.1T SIN vector (Fig. 5D,F,H, insets). Transduced striatal cells appeared to be both medium-sized spiny and aspiny neurons.
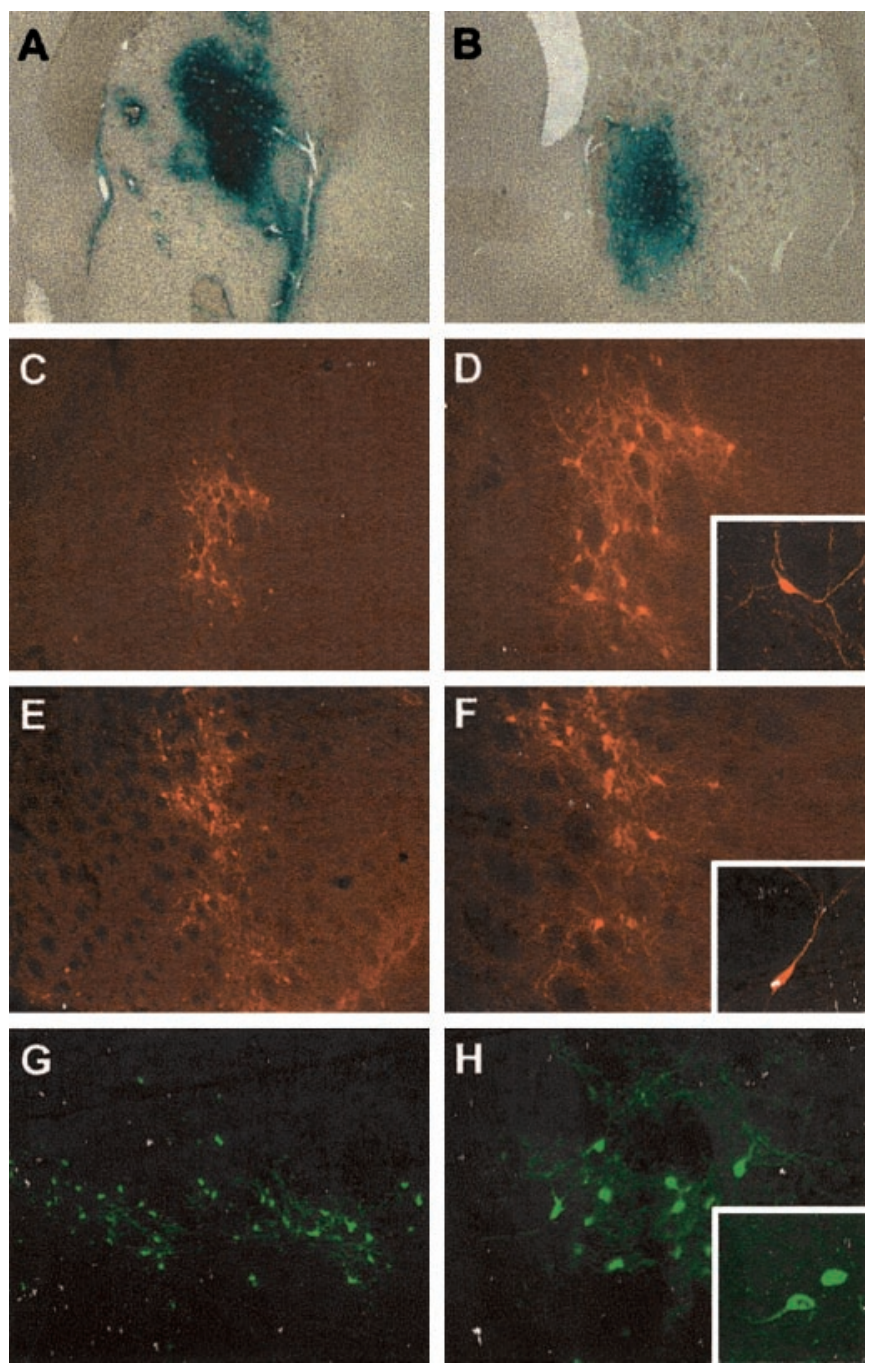

Figure 5. Transduction efficiency of pONY8.1Z SIN $(A, B)$ and pONY8.1T SIN $(C-H)$ in 6-OHDA-lesioned striatum 10 weeks after viral injections. Extensive reporter gene expression was observed in the striatum from the first $(A)$ to the third $(B)$ sites of pONY8.1Z SIN injection, and transduction was comparable with the data obtained with pONY8.0Z (Mazarakis et al., 2001). Expression of HA-AADC $(C, D)$, C-myc-TH $(E, F)$, and Flag-CH1 $(G, H)$ in pONY8.1T SIN-injected striatum was confirmed by immunocytochemistry, and robust transduction was observed with each of the tags. For each tag, $D, F, H$ are higher magnifications of $C, E, G$, respectively, and the insets show confocal images of transduced cells with neuronal morphology. Magnification: $A$, $B, 10 \times ; C, E, G, 25 \times ; D, F, H, 50 \times$, insets, $120 \times$.

\section{Long-term transgene expression and neuronal specificity of pONY8.1T SIN-mediated gene transfer}

Five months after injection with pONY8.1T SIN, HA, C-myc, and Flag expression was detected in $5400 \pm 700,4300 \pm 500$, and $15,400 \pm 2100$ striatal cells, respectively (Fig. $6 A, G, M$ for HA, $\mathrm{C}$-myc, Flag tags, respectively). By comparison with histological data obtained at 10 weeks after transduction, these data indicate that transgene expression is stable for long periods (at least 5 months). Labeling was observed over average rostrocaudal and lateral distances of $2.7 \pm 0.2$ and $1.1 \pm 0.12 \mathrm{~mm}$, respectively. As described previously, examination of the morphology of transduced cells suggested that these cells were predominantly neurons. Neuronal specificity of pONY8.1T SIN-mediated gene 

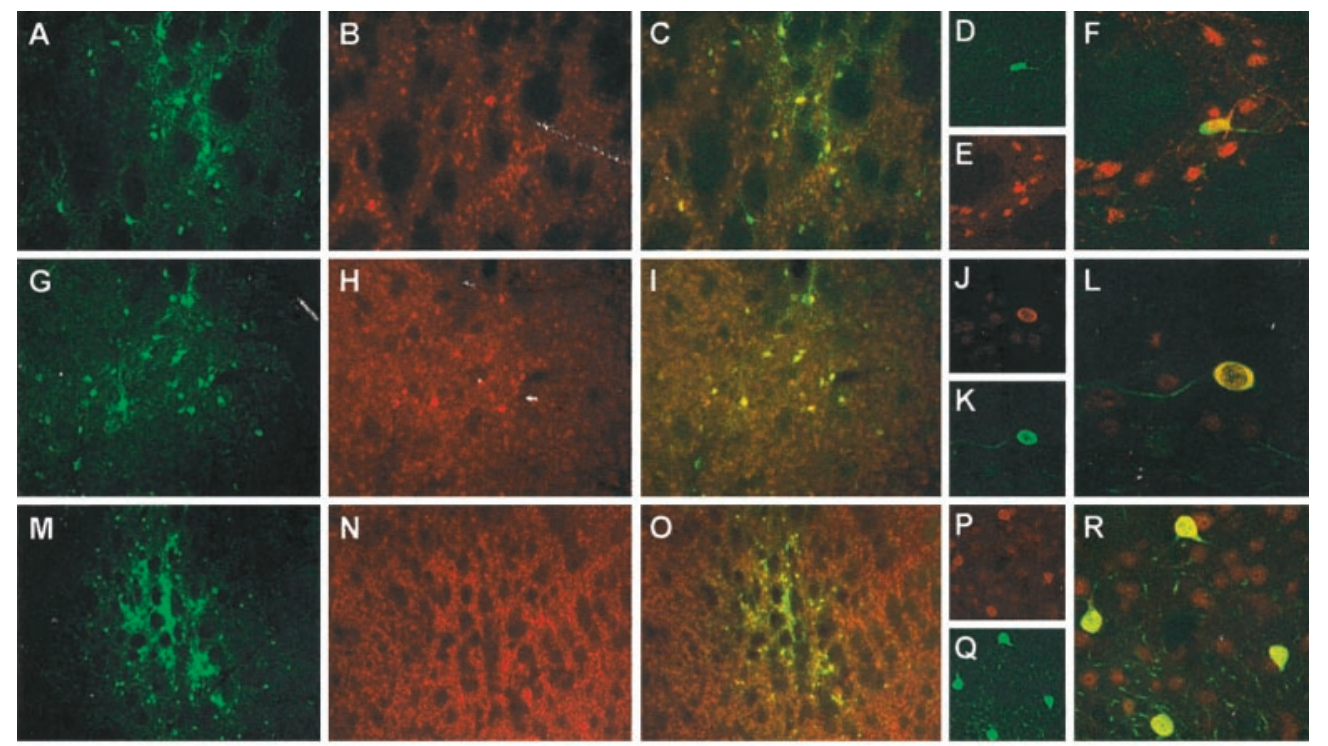

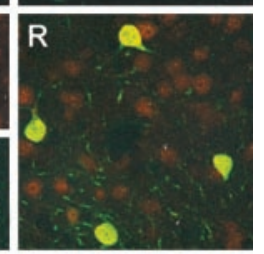

Figure 6. Long-term (5 months) expression and neuronal specificity after transduction with pON Y8.1T SIN viral vectors. Extensive gene transfer at the site of injection in the caudate putamen was observed by immunocytochemistry 5 months after pONY8.1T SIN viral delivery. Each of the three tagged enzymes, HA-AADC $(A)$, C-myc-TH $(G)$, and Flag-CH1 $(M)$, was detected and colocalized with NeuN staining $(B$, $H, N)$ as shown in the merged images $(C$, $I, O)$. Confocal analysis of the transduced cell types in the rat pONY8.1TSIN-injected striatum $(D-F, J-L, P-R)$ showed that the transduced cells were neurons, as demonstrated with HA $(D)$, C-myc $(J)$, Flag $(P)$, and NeuN staining $(E, K, Q)$ in the same sections. Colocalization of tags and NeuN expression can be seen in yellow in the merged images $(F, L, R)$. Magnification: $A-C, G-I$, $M-O, 25 \times ; D-F, P-R, J-L, 120 \times$. transfer was confirmed using double labeling of HA (Fig. 6A-F), C-myc (Fig. 6G-L), and Flag (Fig. 6M-R) tags with anti-NeuN antibodies. Confocal colocalization studies showed that most $(95 \%)$ of the striatal cells that expressed the tags were neurons (Fig. $6 D-F, J-L, P-R$ ).

To confirm transgene expression at 5 months after injection of pON Y8.1T SIN, additional immunolabeling was performed using antibodies against AADC and TH (Fig. 7A,B). TH- and AADCpositive cells were found over 1.5 and $2 \mathrm{~mm}$ along the rostrocaudal axis. This experiment further confirmed the data obtained with the tags (see above). Observation of sections stained for AADC and hematoxylin and eosin showed clear evidence of the presence of the needle tract with minor tissue reaction and absence of perivascular cuffing (Fig. 7A). This is consistent with our previous data, which showed that VSV-G pseudotyped EIAV vectors do not cause significant inflammation (Mazarakis et al., 2001).

Coexpression of the three enzymes in striatal neurons was analyzed by dual immunofluorescence. Double labeling with both anti-AADC and anti-C-myc (TH) antibodies or with anti-AADC and anti-Flag (CH1) indicated most AADC-IR cells were also positive for $\mathrm{TH}$ and $\mathrm{CH} 1$ (Fig. $7 \mathrm{C}-\mathrm{H}$ ).

To determine whether the transduction with pONY8.1T SIN vectors affected the cell viability or the expression of neuronal markers in striatal neurons, immunolabeling was performed using cresyl violet and with antibodies against ChAT and DARPP32. No differences were evident in sections from uninjected or pONY8.1Z SIN- or pONY8.1T SIN-transduced brains stained with cresyl violet (Fig. $8 A-C$ ). In sections stained with the ChAT antibody, 145,710 $\pm 3240,139,900 \pm 6570$, and 144,890 \pm 2570 cells were counted in uninjected and pONY8.1Z SIN- and pON Y8.1T SIN-transduced sections, respectively indicating that there is no loss of cholinergic innervation in the transduced striatum (Fig. 8D-F). Similarly, 347,680 \pm 1349 and 355,730 \pm 2347 DARPP32-positive cells were observed in pON Y8.1Z SINand pONY8.1T SIN-transduced striatum, respectively (Fig. 8G$I)$, further suggesting that there is no loss of cell viability or expression of neuronal markers induced by intrastriatal injection of pONY8.1Z SIN or pONY8.1T SIN.

\section{Catecholamine production in the 6-OHDA lesioned rats injected with EIAV tricistronic vectors}

To determine whether the behavioral recovery could be correlated with biochemical changes, catecholamine levels in the striatum were measured by HPLC. Both dopamine and DOPAC were detected in the lesioned as well as the unlesioned striata (Fig. 7I). The catecholamine level in the lesioned striatum of rats injected with the pONY8.1T SIN vector was higher (approximately threefold) than that in control animals injected with pONY8.1Z SIN. This suggests that dopamine and DOPAC are synthesized in the striata of animals transduced with pON Y8.1T SIN. However, the amount of dopamine produced in the lesioned striata did not exceed $3.6 \%$ of the amount found in the unlesioned striata (Fig. 7I) but was still sufficient to provide a behavioral correction. The DOPAC/DA ratio was also higher in the lesioned striatum compared with the unlesioned side, as expected of a denervated striatum.

\section{DISCUSSION}

The data presented in this report show that injection of the EIAV viral vector, pONY8.1T SIN, into the 6-OHDA-lesioned rat striatum leads to the following: (1) transduction and long-term expression of the AADC, $\mathrm{TH}$, and $\mathrm{CH} 1$ enzymes in the striatum; (2) effective production of catecholamines; and (3) significant and persistent reduction of apomorphine-induced motor asymmetry. EIAV lentiviral vectors have been shown to be promising vectors for gene transfer in the nervous system, because they allow robust and long-term expression of reporter genes in postmitotic neurons (Martin-Rendon et al., 2001). This report is the first to demonstrate that (1) EIAV vectors can mediate gene therapy in an animal model of human disease; (2) multicistronic lentiviral vectors can cotransduce several genes into the CNS; and (3) lentiviral vectors can correct a model of PD using a dopamine replacement approach.

The enzymes to be used in a gene therapy approach to effectively produce dopamine have been established previously (Kang, 1998; Kang et al., 2001). Tyrosine hydroxylase catalyzes the ratelimiting step in the biosynthesis of the catecholamines dopamine, norepinephrine, and epinephrine. Therefore, the regulation of tyrosine hydroxylase enzyme expression and intrinsic enzyme ac- 

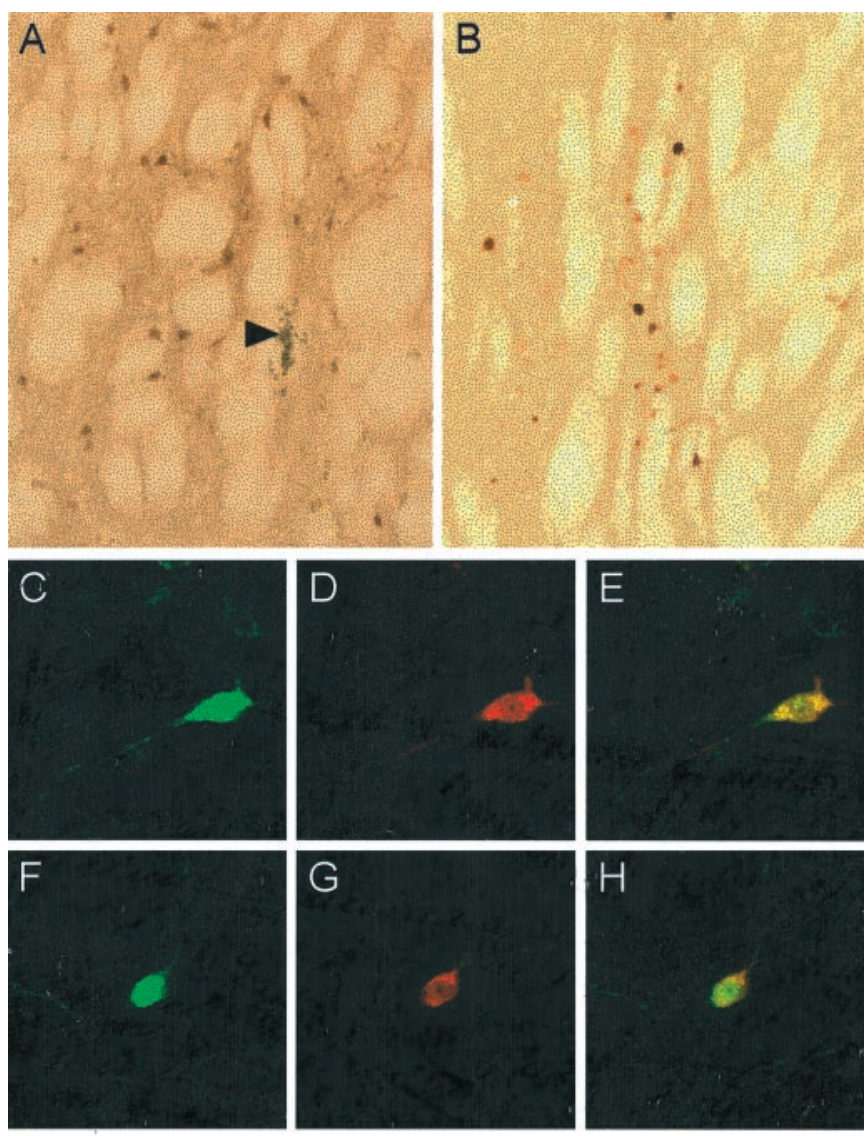

(l)

\begin{tabular}{|c|c|c|c|c|}
\hline \multirow[b]{2}{*}{ Vector Injected } & \multicolumn{2}{|c|}{ Uniesioned } & \multicolumn{2}{|c|}{ Lesionied } \\
\hline & DA & DOPAC & $\mathrm{DA}$ & DOPAC \\
\hline pONY8.1Z SIN & 5680 & 1250 & 12 & 20 \\
\hline pONY8.1Z SIN & 8112 & 1532 & 82 & 72 \\
\hline pONY8.1T SIN & 7160 & 1450 & 100 & 172 \\
\hline PONY8.1T SIN & 7500 & 770 & 135 & 126 \\
\hline pONY8.1T SIN & 4216 & 1424 & 152 & 146 \\
\hline
\end{tabular}

Figure 7. Specific viral vector-mediated expression of AADC and TH in the denervated striatum 5 months after pONY8.1T SIN delivery. Photomicrographs demonstrate $\operatorname{AADC}(A)$ and TH $(B)$ expression, and confocal microscopic images reveal the colocalization of expression of AADC $(C, F)$ with either Flag $(D)$ or C-myc $(G)$ antibodies. Composite confocal images show colocalization of AADC and Flag $(E)$ or C-myc $(H)$ in yellow. The arrowhead in $A$ shows clear evidence of the presence of the needle tract with minor tissue reaction and the absence of damage to the striatum. Magnification: $A, B, 25 \times ; C-H, 120 \times$. In similarly treated animals, in vivo synthesis of catecholamines in the striata of 6-OHDAlesioned rats injected with either pONY8.1Z SIN or pONY8.1T SIN is demonstrated. I, Levels of dopamine and DOPAC (picograms per milligram of wet tissue) in lesioned and unlesioned striata measured by HPLC with electrochemical detection.

tivity represents the central means for controlling the synthesis of these important biogenic amines. By contrast to other studies, a truncated form of $\mathrm{TH}$ was used in the present study that should prevent feedback inhibition by dopamine (Kumer and Vrana, 1996). Ideally, as the rate-limiting step in dopamine synthesis, the TH would have been the first enzyme in the tricistronic cassette. However, because TH has a canonical Kozac sequence, this gene had to be placed downstream of the EMCV IRES in the pONY8.1T SIN vector (Davies and Kaufman, 1992). It is known that the expression of genes after an IRES is reduced (Metz et al., 1998), but it is clear that sufficient expression was obtained for functional activity of both the tetrameric TH and decameric $\mathrm{CH}$. Whether the position of the TH gene has significantly limited the expression of this enzyme with a concomitant decrease in dopamine production is not known.

Transduction of the denervated striatum with pON Y8.1T SIN leads to AADC, TH, and CH1 expression in $5000 \pm 700,4800 \pm$ 400 , and 16,000 \pm 1400 cells, respectively. These results indicate a threefold lower number of cells in which expression of AADC and $\mathrm{TH}$ can be detected compared with cells expressing $\mathrm{CH} 1$. This may be a result of differences in antibody avidity or that $\mathrm{TH}$ and AADC are not as stable as they may be in the neurons of the substantia nigra pars compacta. Nevertheless, these data still demonstrate relatively high transgene expression compared with the number of $\mathrm{TH}+$ cells that were necessary for functional effects in fetal mesencephalic graft studies (Brundin et al., 1988). Furthermore, although the numbers of pONY8.1T SIN-transduced cells are apparently lower than the number of cells transduced with monocistronic vectors (Shen et al., 2000; Kirik et al., 2002), it is clear that functional recovery is observed in this study. One explanation for this phenomenon is that expression of both $\mathrm{TH}$ and AADC is required for dopamine synthesis. Consequently, the number of cells that may be double- or triple-transduced with each of the monocistronic vectors in these studies, rather than transduced with only one vector, may be equivalent to the number of cells transduced in this study.

Expression of TH, AADC, and $\mathrm{CH} 1$ as a result of transduction with pONY8.1T SIN in the 6-OHDA-lesioned striatum decreases the apomorphine-induced rotational motor asymmetry by $\sim 48 \%$. By comparison, previous studies have shown that triple transduction of the striatum with AAV-TH, AAV-AADC, and AAV-CH elicited a 50-60\% decrease in drug-induced turns (Shen et al., 2000). The data presented in this study are comparable with those reported by Shen et al. (2000). However, the strategy presented here has a powerful advantage, because coexpression of the three enzymes in the same cell is ensured. These data showing decreased apomorphine-induced rotations are also consistent with other studies using human immunodeficiency virus (HIV)-based lentiviral or adenoviral vectors encoding GDNF. These vectors have induced 50 and $40 \%$ decreases in apomorphine-induced motor asymmetry associated with 6-OHDA lesions in rodents, respectively (Lapchak et al., 1997; Bensadoun et al., 2000). Similarly, intrastriatal mesencephalic grafts in rat have induced at least a 50\% reduction in net turning (Brundin et al., 1988), and in a second transplantation study, a 54\% decrease in druginduced motor asymmetry after intranigral fetal mesencephalic grafts has been demonstrated (Nikkhah et al., 1994).

The decrease in apomorphine-induced rotations in our study is most likely caused by enhanced dopamine production, because biochemical analysis showed increased dopamine and DOPAC in the pON Y8.1T SIN-injected striata compared with controls. No good correlation between the functional correction of the motor asymmetry and catecholamine levels was observed per individual animal, but this has also been observed in other studies using apomorphine in 6-OHDA-treated rats (Bensadoun et al., 2000). However, increased dopamine turnover in lesioned striata injected with pONY8.1T SIN and pONY8.1Z SIN vectors was observed compared with the unlesioned striata. This indicates that the amount of dopamine produced is small and reflects 

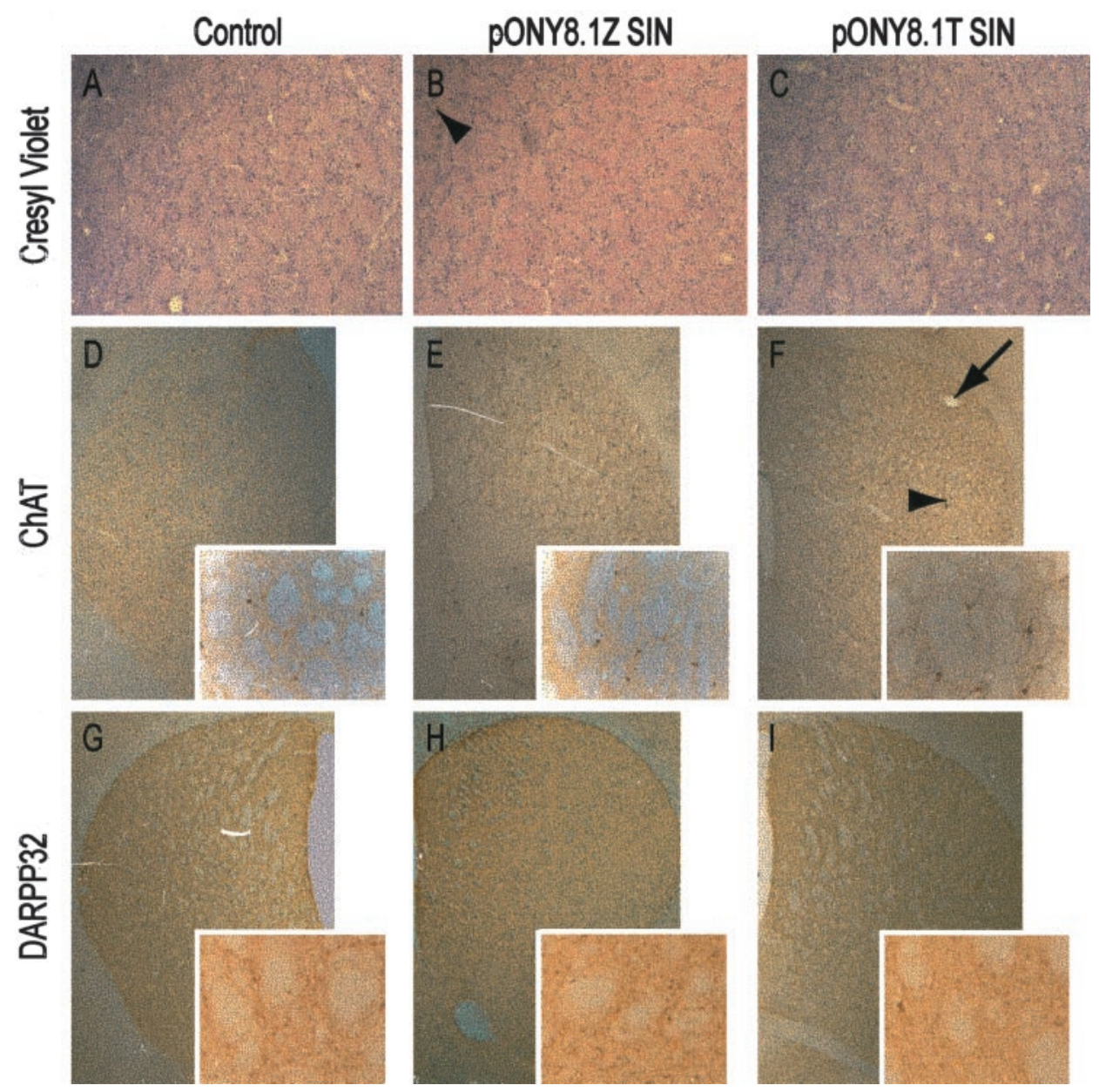

Figure 8. Evaluation of cytotoxicity in striatal neurons in vivo after EIAV vector transduction and increased dopamine turnover. Photomicrographs demonstrate cresyl violet staining $(A-C)$ and antiChAT $(D-F$, insets) and anti-DARPP32 $(G-I$, insets) immunostaining on striatal sections from control $(A, D, G)$ and pONY8.1Z SIN-injected $(B, E, H)$ and pON Y8.1T SIN-injected striata $(C, F, I)$. No damage or reduction of the number of striatal neurons is observed. Insets show normal morphology of ChAT- or DARPP32-positive neurons in pONY8.1T SIN-injected brain compared with pONY8.1Z SIN and control striata. $A r$ rowheads in $B$ and $F$ indicate needle tracts, and the arrow in $F$ indicates a needle mark made during brain sectioning for recognition of the right striatum. Magnification: $A-C, 25 \times ; D-I, 10 \times$; insets, $50 \times$. enhanced dopamine release and metabolism from the transduced cells. Therefore, it would be interesting to see whether delivering increased transducing units of viral vector could induce better correction and normalize dopamine turnover.

Dopamine replacement in the striatum seems to be important for behavioral recovery. A relatively small increase in dopamine production $(<5 \%)$ appears to have a marked therapeutic effect. Most striatal neurons express DA receptors that are internalized in response to alterations in dopaminergic tone (Dumartin et al., 1998; Muriel et al., 1999). Dopamine produced in striatal neurons transduced with pON Y8.1T SIN vectors might bind cytoplasmic DA receptors in addition to being released by a nonsynaptic mechanism. Alternatively, as these neurons become depolarized, dopamine is coreleased and interacts with the D1 receptors in an autocrine manner.

A number of studies have drawn attention to the toxicity that can be mediated by some intermediates of dopamine (Barzilai et al., 2001). Because dopamine was to be produced in nondopaminergic striatal neurons, there was the possibility that cytosolic dopamine might cause cell death in this approach. This was not found to be the case both in striatal neurons in vitro and also in vivo in the 6-OHDA-denervated striatum for long periods after transduction. It is possible that only small amounts of dopamine are produced and that this is detoxified effectively by striatal neurons. Proteins such as $\alpha$-synuclein (Sulzer, 2001) might have a neuroprotective role in this, or packaging into vesicles via transporters other than VMAT2 could be occurring.

The good levels and longevity of expression of the pONY8.1T
SIN vector are encouraging for the use of these vectors in the treatment of Parkinson's disease and other progressive neurodegenerative diseases. This has been shown previously with marker genes for both EIAV and HIV vectors and with other therapeutic genes for HIV vectors (Kordower et al., 1999; Bensadoun et al., 2000; Deglon et al., 2000; Hottinger et al., 2000; Kordower et al., 2000; Mazarakis et al., 2001). A notable difference, however, is that the EIAV system used here did not have any of the enhancer elements (central polypurine tract or the woodchuck hepatitis virus post-transcriptional regulatory element) used in the HIV vectors and that pONY8.1T SIN also uses the CMV promoter rather than the phosphoglycerate kinase promoter. The use of these elements and alternative promoters might further increase production of dopamine from EIAV vectors, probably leading to increased behavioral improvement.

This study represents an important step toward developing an effective long-term gene therapy to achieve dopamine replacement in PD patients.

\section{REFERENCES}

Abercrombie M (1946) Estimation of nuclear population from microtome sections. Anat Rec 94:239-247.

Ariano MA, Sortwell CE, Ray M, Altemus KL, Sibley DR, Levine MS (1997) Agonist-induced morphologic decrease in cellular D1A dopamine receptor staining. Synapse 27:313-321.

Bankiewicz KS, Eberling JL, Kohutnicka M, Jagust W, Pivirotto P, Bringas J, Cunningham J, Budinger TF, Harvey-White J (2000) Convection-enhanced delivery of AAV vector in parkinsonian monkeys; in vivo detection of gene expression and restoration of dopaminergic function using pro-drug approach. Exp Neurol 164:2-14. 
Barker RA, Dunnett SB (1999) Functional integration of neural grafts in Parkinson's disease. Nat Neurosci 2:1047-1048.

Barzilai A, Melamed E, Shirvan A (2001) Is there a rationale for neuroprotection against dopamine toxicity in Parkinson's disease? Cell Mol Neurobiol 21:215-235.

Bensadoun JC, Deglon N, Tseng JL, Ridet JL, Zurn AD, Aebischer P (2000) Lentiviral vectors as a gene delivery system in the mouse midbrain: cellular and behavioural improvements in a 6-OHDA model of Parkinson's disease using GDNF. Exp Neurol 164:15-24.

Bjorklund A, Kirik D, Rosenblad C, Georgievska B, Lunberg C, Mandel RJ (2000) Towards a neuroprotective gene therapy for Parkinson's disease: use of adenovirus, AAV and lentivirus vectors for gene transfer of GDNF to the nigrostriatal system in the rat Parkinson model. Brain Res 886:82-98.

Brundin P, Barbin G, Strecker RE, Isacson O, Prochiantz A, Bjorklund A (1988) Survival and function of dissociated rat dopamine neurones grafted at different developmental stages or after being cultured in vitro. Brain Res 467:233-243.

Davies MV, Kaufman RJ (1992) The sequence context of the initiation codon in the encephalomyocarditis virus leader modulates efficiency of internal translation initiation. J Virol 66:1924-1932.

Deglon N, Tseng JL, Bensadoun JC, Zurn AD, Arsenijevic Y, Pereira de Almeida L, Zufferey R, Trono D, Aebischer P (2000) Self-inactivating lentiviral vectors with enhanced transgene expression as potential gene transfer system in Parkinson's disease. Hum Gen Ther 11:179-190.

Dumartin B, Caille I, Gonon F, Bloch B (1998) Internalization of D1 dopamine receptor in striatal neurons in vivo as evidence of activation by dopamine agonists. J Neurosci 18:1650-1661.

Dunnett SB, Bjorklund A (1992) Staging and dissection of rat embryos: the practical approach series. Oxford: IRL.

Fan DS, Ogawa M, Fujimoto KI, Ikeguchi K, Ogasawara Y, Urabe M, Nishizawa M, Nakano I, Yoshida M, Nagatsu I, Ichinose H, Nagatsu T, Kurtzman GJ, Ozawa K (1998) Behavioral recovery in 6-hydroxydopamine-lesioned rats by cotransduction of striatum with tyrosine hydroxylase and aromatic L-amino acid decarboxylase gene using two separate adeno-associated virus vectors. Hum Gene Ther 9:2527-2535.

Freed CR, Greene PE, Breeze RE, Tsai WY, DuMouchel W, Kao R, Dillons S, Winfield H, Culver S, Trojanowski JQ, Eidelberg D, Fahn S (2001) Transplantation of embryonic dopamine neurons for severe Parkinson's disease. N Engl J Med 344:710-719.

Hoehn MM, Yahr MD (1967) Parkinsonism: onset, progression and mortality. Neurology 17:427-442.

Hottinger AF, Azzouz M, Deglon N, Aebischer P, Zurn AD (2000) Complete and long-term rescue of lesioned adult motoneurons by lentiviral-mediated expression of glial cell line-derived neurotrophic factor in the facial nucleus. J Neurosci 20:5587-5593.

Kang UJ (1998) Potential of gene therapy for Parkinson's disease: neurobiologic issues and new developments in gene transfer methodologies. Mov Disord 13 [Suppl 1]:59-72.

Kang UJ, Lee WY, Chang JW (2001) Gene therapy for Parkinson's disease: determining the genes necessary for optimal dopamine replacement in rat models. Hum Cell 14:39-48.

Kirik D, Georgievska B, Burger C, Winkler C, Muzyczka N, Mandel RJ, Bjorklund A (2002) Reversal of motor impairments in parkinsonian rats by continuous intrastriatal delivery of L-dopa using rAAVmediated gene transfer. Proc Natl Acad Sci USA 99:4708-4713.

Kish S, Shannak K, Hornykiewicz O (1988) Uneven pattern of dopamine loss in the striatum of patients with idiopathic Parkinson's disease: pathophysiologic and clinical implications. N Engl J Med 318:876-880.

Kordower JH, Bloch J, Ma SY, Chu Y, Palfi S, Roitberg BZ, Emborg M, Hantraye P, Deglon N, Aebischer P (1999) Lentiviral gene transfer to the non-human primate brain. Exp Neurol 160:1-16.

Kordower JH, Emborg ME, Bloch J, Ma SY, Chu Y, Leventhal L, McBride J, Chen EY, Palfi S, Roiterg BZ, Brown WD, Holden JE, Pyzalski R, Taylor MD, Carvey P, Ling Z, Trono D, Hantraye P, Deglon N, Aebischer P (2000) Neurodegeneration prevented by lentiviral vector delivery of GDNF in primate models of Parkinson's disease. Science 290:767-773.

Kumer SC, Vrana KE (1996) Intricate regulation of tyrosine hydroxylase activity and gene expression. J Neurochem 67:443-462.

Lapchak PA, Araujo DM, Hilt DC, Sheng J, Jiao S (1997) Adenoviral vector-mediated GDNF gene therapy in a rodent lesion model of late stage Parkinson's disease. Brain Res 777:153-160.

Leff SE, Rendahl KG, Spratt SK, Kang UJ, Mandel RJ (1998) In vivo L-DOPA production by genetically modified primary rat fibroblast or 9L gliosarcoma cell grafts via coexpression of GTPcyclohydrolase I with tyrosine hydroxylase. Exp Neurol 151:249-264.

Leff SE, Spratt SK, Snyder RO, Mandel RJ (1999) Long-term restoration of striatal L-aromatic amino acid decarboxylase activity using recombinant adeno-associated viral vector gene transfer in a rodent model of Parkinson's disease. Neuroscience 92:185-196.

Levey AI, Hersch SM, Rye DB, Sunahara RK, Niznik HB, Kitt CA, Price DL, Maggio R, Brann MR, Ciliax BJ (1993) Localization of D1 and D2 dopamine receptors in brain with subtype-specific antibodies. Proc Natl Acad Sci USA 90:8861-8865.
Mandel RJ, Rendahl KG, Spratt SK, Snyder RO, Cohen LK, Leff SE (1998) Characterization of intrastriatal recombinant adeno-associated virus-mediated gene transfer of human tyrosine hydroxylase and human GTP-cyclohydrolase I in a rat model of Parkinson's disease. J Neurosci 18:4271-4284.

Martin-Negrier M, Charron G, Bloch B (2000) Agonist stimulation provokes dendritic and axonal dopamine $\mathrm{D}(1)$. receptor redistribution in primary cultures of striatal neurons. Neuroscience 99:257-266.

Martin-Rendon E, Azzouz M, Mazarakis ND (2001) Lentiviral vectors for the treatment of neurodegenerative diseases. Curr Opin Mol Ther 3:476-481.

Martin-Rendon E, White J, Olsen A, Mitrophanous K, Mazarakis N (2002) New methods to titrate EIAV-based lentiviral vectors. Mol Ther 5:566-570.

Mazarakis ND, Azzouz M, Rohll JB, Ellard FM, Wilkes FJ, Olsen AJ, Carter EE, Barber RD, Baban DF, Kingsman SM, Kingsman AJ, O'Malley K, Mitrophanous KA (2001) Rabies virus glycoprotein pseudotyping of lentiviral vectors enables retrograde axonal transport and access to the nervous system after peripheral delivery. Hum Mol Genet 10:2109-2121.

Metz MZ, Pichler A, Kuchler K, Kane SE (1998) Construction and characterization of single-transcript tricistronic retroviral vectors using two internal ribosome entry sites. Somat Cell Mol Genet 24:53-69.

Mitrophanous KA, Yoon S, Rohll JB, Patil D, Wilkes F, Kim V, Kingsman SM, Kingsman AJ, Mazarakis ND (1999) Stable gene transfer to the nervous system using a non-primate lentiviral vector. Gene Ther 6:1808-1818

Muramatsu S, Fujimoto K, Ikeguchi K, Shizuma N, Kawasaki K, Ono F, Shen Y, Wang L, Mizukami H, Kume A, Matsumura M, Nagatsu I, Urano F, Ichinose H, Nagatsu T, Terao K, Nakano I, Ozawa K (2002) Behavioral recovery in a primate model of Parkinson's disease by triple transduction of striatal cells with adeno-associated viral vectors expressing dopamine-synthesizing enzymes. Hum Gene Ther 13:345-354.

Muriel MP, Bernard V, Levey AI, Laribi O, Abrous DN, Agid Y, Bloch B, Hirsch EC (1999) Levodopa induces a cytoplasmic localization of D1 dopamine receptors in striatal neurons in Parkinson's disease. Ann Neurol 46:103-111.

Nagatsu T (1992) Molecular biology of dopamine systems. In: Controversies in the treatment of Parkinson's disease' (Rinne UK, Yanagisawa N, eds), pp 15-26. Tokyo: PMSI.

Nagatsu T, Ichinose H (1997) GTP cyclohydrolase I gene, dystonia, juvenile parkinsonism, and Parkinson's disease. J Neural Transm [Suppl] 49:203-209.

Nikkhah G, Bentlage C, Cunningham MG, Bjorklund A (1994) Intracranial fetal dopamine grafts induce behavioural compensation in the rat Parkinson model. J Neurosci 14:3449-3461.

Piccini P, Brooks DJ, Bjorklund A, Gunn RN, Grasby PM, Rimoldi O, Brundin P, Hagell P, Rehncrona S, Widner H, Lindwall O (1999) Dopamine release from nigral transplants visualized in vivo in a Parkinson's patient. Nat Neurosci 2:1137-1040.

Rohll JB, Mitrophanous KM, Martin-Rendon E, Radcliffe PA, Mazarakis ND, Kingsman SM (2002) The design, production, safety, evaluation and clinical applications of non-primate lentiviral vectors. Methods Enzymol 346:466-500.

Sanchez-Pernaute R, Harvey-White J, Cunningham J, Bankiewicz KS (2001) Functional effect of adeno-associated virus mediated gene transfer of aromatic L-amino acid decarboxylase into the striatum of 6-OHDA-lesioned rats. Mol Ther 4:324-330.

Shen Y, Muramatsu SI, Ikeguchi K, Fujimoto KI, Fan DS, Ogawa M, Mizukami H, Urabe M, Kume A, Nagatsu I, Urano F, Suzuki T, Ichinose H, Nagatsu T, Monahan J, Nakano I, Ozawa K (2000) Triple transduction with adeno-associated virus vectors expressing tyrosine hydroxylase, aromatic L-amino acid decarboxylase and GTPcyclohydrolase I for gene therapy of Parkinson's disease. Hum Gene Ther 11:1509-1519.

Soneoka Y, Cannon PM, Ramsdale EE, Griffiths JC, Romano G, Kingsman SM, Kingsman AJ (1995) Transient three-plasmid expression system for the production of high titer retroviral vectors. Nucleic Acids Res 23:628-633.

Stutts MJ, Canessa CM, Olsen JC, Hamrick M, Cohn JA, Rossier BC, Boucher RC (1995) CFTR as a cAMP-dependent regulator of sodium channels. Science 269:847-850.

Sulzer D (2001) Alpha-synuclein and cytosolic dopamine: stabilizing a bad situation. Nat Med 7:1280-1282.

Szczypka MS, Mandel RJ, Donahue BA, Snyder RO, Leff SE, Palmiter RD (1999) Viral gene delivery selectively restores feeding and prevents lethality of dopamine-deficient mice. Neuron 22:167-178.

Szczypka MS, Kwok K, Brot MD, Marck BT, Matsumoto AM, Donahue BA, Palmiter RD (2001) Dopamine production in the caudate putamen restores feeding in dopamine-deficient mice. Neuron 30:819-828.

Wood MJ, Byrnes AP, Kaplitt MG, Pfaff DW, Rabkin SD, Charlton HM (1994) Specific patterns of defective HSV-1 gene transfer in the adult central nervous system: implications for gene targeting. Exp Neurol 130:127-140. 